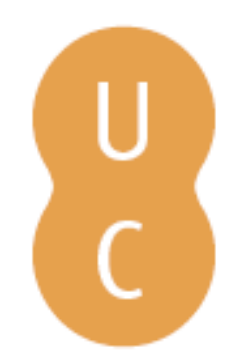

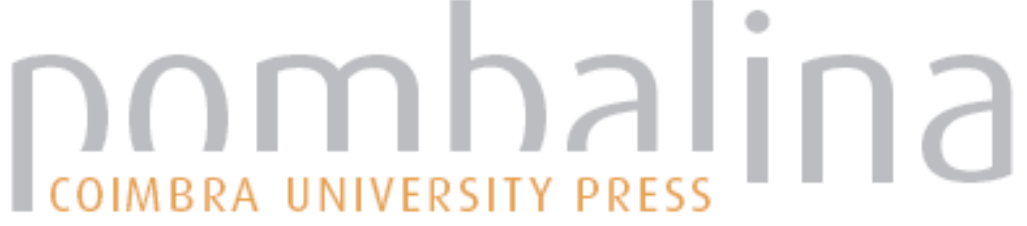

\section{Entardecer em Mitilene de Andrés Pociña}

Autor(es): $\quad$ Silva, Maria de Fátima (trad.)

Publicado por: Imprensa da Universidade de Coimbra

URL

persistente:

URI:http://hdl.handle.net/10316.2/44263

DOI:

DOI:https://doi.org/10.14195/978-989-26-1526-4_5

Accessed : $\quad$ 26-Apr-2023 03:14:01

A navegação consulta e descarregamento dos títulos inseridos nas Bibliotecas Digitais UC Digitalis, UC Pombalina e UC Impactum, pressupõem a aceitação plena e sem reservas dos Termos e Condições de Uso destas Bibliotecas Digitais, disponíveis em https://digitalis.uc.pt/pt-pt/termos.

Conforme exposto nos referidos Termos e Condições de Uso, o descarregamento de títulos de acesso restrito requer uma licença válida de autorização devendo o utilizador aceder ao(s) documento(s) a partir de um endereço de IP da instituição detentora da supramencionada licença.

Ao utilizador é apenas permitido o descarregamento para uso pessoal, pelo que o emprego do(s) título(s) descarregado(s) para outro fim, designadamente comercial, carece de autorização do respetivo autor ou editor da obra.

Na medida em que todas as obras da UC Digitalis se encontram protegidas pelo Código do Direito de Autor e Direitos Conexos e demais legislação aplicável, toda a cópia, parcial ou total, deste documento, nos casos em que é legalmente admitida, deverá conter ou fazer-se acompanhar por este aviso. 


\section{MEDEIA, SAFO, ANTÍGONA}

\section{MITOS ETERNOS, NOVAS LEITURAS}

\section{ANDRÉS POCIÑA}




\title{
ENTARDECER EM MITILENE \\ DE ANDRÉS POCIÑA
}

(Tradução de Maria de Fátima Silva)

\author{
Em recordação de Mary Carrillo, \\ que nos deixou no próprio dia em que acabei esta obra, \\ e para Mercedes Arriaga, Aurora López, Mariana \\ Lozano, Carmen Morenilla, Lucía Romero, Begoña \\ Sánchez e Maria de Fátima Silva, \\ que acreditaram que eu podia escrever teatro. \\ 31-VIII-2009
}

DRAMATIS PERSONAE

SAFO, entre quarenta e cinquenta anos. Usa uma túnica ligeira, de cor branca; tem o cabelo preso num penteado elegante, entrançado com uma fita de cor verde claro. Figura muito esbelta; não propriamente formosa.

TELESIPA

MÉGARA

GÔNGILA

IRANA

GIRINA

FILÉNIS

Moças jovens, que vivem na casa de Safo. Vestem túnicas frescas, compridas, pelo meio da perna, talvez adornadas com fitas, grinaldas, flores. Dão uma imagem alegre, jovial, festiva.

PORTEIRO, jovem, ainda adolescente; personagem muda. 
Pátio de uma casa, semelhante aos de Córdoba, com muitas plantas espalhadas pelas paredes brancas, gerânios, com as floreiras colocadas em suportes de arame pintado de verde escuro. É rico o colorido das floreiras. As paredes são caiadas, e no início da obra uma das moças, Telesipa, em cima de um banco, está a dar-lhes uma mão de cal, com uma brocha presa a um cabo de cana; outra, Gôngila, em cima de um tamborete baixo, pinta de verde um dos suportes das floreiras. As outras quatro estão sentadas em redor de Safo, em cadeiras de vime. Sobressai entre elas o assento de Safo, um cadeirão, também de vime, mas com mais porte.

É o entardecer de um dia de verão que foi sufocante.

(N. B.: Os versos em itálico incluídos no texto pertencem a Safo e não deverão alterar-se; não são autênticos outros que se lhe atribuem, que aparecem em redondo.)

\section{TELESIPA (a caiar as paredes do pátio)}

Não posso mais, por Afrodite. Parece mentira como os braços se cansam quando se pinta as partes altas! E como dificultam o trabalho tantas floreiras! Basta um descuido, e a brocha toca nos gerânios. E para mais um calor assim durante toda a tarde!

\section{SAFO}

Tens toda a razão, Telesipa. Pára de caiar, por uma vez; amanhã acabas. Talvez amanheça um dia mais suportável. Também eu estou com uma dor de cabeça tremenda.

\section{MÉGARA (sentada)}

Queres que te vá buscar um copo de água fresca, Safo? É que não descansaste um instante em todo o dia. (A Telesipa) Tu, em compensação, não é preciso tantas queixas. Há uns meses atrás pintei eu os quartos e ninguém ouviu da minha boca um queixume que fosse.

GÔNGILA (sentada a pintar um suporte de floreiras)

Pois bem, filha, já sabes o que tens a fazer. Podes acabar a tarefa de Telesipa e, se ainda tiveres coragem, passo-te a minha também. Que tu, já se sabe, és sempre a primeira, sempre a menina exemplar ...

MÉGARA (reagindo, enérgica)

E tu também já se sabe: que ninguém toque num só cabelo de Telesipa. Ponha-se ela a pintar, tu pões-te a pintar; dá-lhe para cantar, tu segunda voz; queixe-se 
ela de alguma coisa, tu uma desgraçadinha ... Sois como Heitor e Andrómaca, no feminino plural: um quadro enternecedor.

SAFO

Vá lá, meninas, não comecem outra vez. Nós não somos o círculo de Andrómeda, com as suas moças que nem recrutas, sempre no pagode. Senta-te, Mégara, e fica sossegada. E tu, Telesipa, pousa-me essa brocha e senta-te aqui, ao meu lado, nesta cadeira. E tu, Gôngila, amanhã acabas esses suportes. Não me parece que os gerânios vão protestar se não terminares hoje.

GÔNGILA

Só me faltam dois, mestra. E amanhã queria era pintar, mas de verdade, alguma coisa interessante.

\section{SAFO}

Muito bem. Traz para aqui esses que te faltam, mas junta-te a nós. Não vá que alguém pense que te temos cá em casa como criada. Filénis, vai lá dentro, por favor, e enche, para todas nós, uns copos de limonada que deixei a refrescar. (Filénis entra pela porta de casa) Não sei o que hei-de fazer, com esta dor de cabeça! Têm alguma sugestão, meninas?

\section{MÉGARA}

Podias recitar-nos alguma coisa, senhora. Por exemplo, aqueles poemas que estavas a escrever esta manhã.

\section{SAFO}

Não, não. Ainda tenho de lhes dar mais uma volta. Nunca uma poeta deve lançar nada ao vento sem antes o ter revisto como deve ser. Não basta duas vezes, mas todas as que forem precisas, até deixá-los bem polidos como o mármore, sem rugosidades nem arestas.

\section{MÉGARA}

A ti saem-te divinos logo à primeira.

\section{SAFO}

Obrigada, Mégara. Embora não seja verdade o que estás a dizer, a tua generosidade não tem limites. 


\section{MÉGARA}

Não se trata de generosidade, Safo. É admiração, é adoração, é reverência. É amor pela tua poesia.

\section{SAFO}

Vá lá! Vá lá! Aplica as tuas palavras a fazer versos, não a bajular-me. Mas a verdade é que tas agradeço do coração.

\section{MÉGARA}

Que versos poderia eu fazer, mestra, ao lado dos teus? Com apenas dois, tu dizes o que nenhuma de nós conseguiria com duzentos:

\section{O amor agitou-me as entranhas}

como um vento que desce dos montes vergando as azinheiras

Qual de nós não teve alguma vez esta sensação, ao ver-te sair do quarto pela manhã, como quando surge no horizonte a Aurora de dedos róseos?

\section{GÔNGILA}

Anda lá, anda lá, senhora! Refreia essa lisonja toda, saída dessa tua admiradora, ou vai acabar por imolar-se aos teus pés. E vamos a coisas mais sérias, por favor. Recita-nos alguma coisa, Safo. Porque não nos dizes outra vez o poema 'Parece ser semelhante a um deus ...'

\section{SAFO}

Outra vez?! Não, pelas Musas todas! Já mo ouviram em mil e uma ocasiões. Não, não! Já me aborrece essa poesia. Vamos fazer outra coisa. Eu digo-vos uma coisita curta, que pensei ontem à noite, e vocês arranjam-lhe uma continuação, pode ser? Vamos lá a ver ... Sim, era o seguinte, muito simples:

$$
\begin{aligned}
& \text { Já se pôs a lua } \\
& \text { e as Plêiades: vai a meio } \\
& \text { a noite, passam-se as horas, } \\
& \text { e eu dormindo só. }
\end{aligned}
$$

MÉGARA (que prossegue, ansiosa)

As estrelas em torno da formosa lua de novo the escondem o resplendor 
quando em plenitude, cheia, ela ilumina a terra inteira ...

SAFO (que a interrompe, não sem alguma brusquidão)

Não, não, Mégara. Assim não vale. Esses versos também são meus. Além disso, o sentido não é consequente entre uma parte e a outra. Não, decididamente, assim não pode ser. Eu quero alguma coisa vossa, de uma de vós, ou de duas, ou de todas. Vamos lá a ver, aqui vai de novo a minha proposta:

Já se pôs a lua

e as Plêiades: vai a meio

a noite, passam-se as horas,

e eu dormindo só.

IRANA (a reflectir em cada palavra, mas com determinação)

Mas espero a alva rosada

para distinguir no horizonte

a tua esbelta escultura,

amor de músculos rijos,

forte na passada qual Ares,

ondeando ao Zéfiro os teus cabelos

e na tua mão, para mim, uma rosa.

SAFO (claramente surpreendida, com voz entrecortada)

É belo, muito belo. Se quisesse fazer-te alguma crítica, querida Irana, talvez te dissesse que ultimamente temos exagerado um pouco com tantos epitalâmios. Claro que a critica deveria aplicar-se-me a mim mesma, às minhas poesias mais recentes. Temos dado demasiada entrada a homens formosos nos nossos versos. (Fica calada um instante, pensando) Talvez também nas nossas existências. (Com decisão) É preciso regressarmos a nós mesmas. Antes de mais a nós mesmas.

GÔNGILA (que continua a pintar um suporte de floreiras, embora parasse enquanto Irana recitava)

Tens razão, senhora. Mas amanhã já vou remediar semelhante problema. Vou pintar para ti um nascimento de Afrodite, a deusa que tanto amas, a surgir das ondas do mar de Chipre.

SAFO (a Filénis, que vem com os copos de limonada numa bandeja, nervosa e sufocada) 
Que grande demora, menina. Bem se podia dizer que ficaste à espera que os limões amadurecessem ... Como se os não tivesse espremido eu mesma ao meio dia ... (Olha-a fixamente nos olhos) Por onde anda o porteiro?

\section{FILÉNIS (hesitante)}

Está na cozinha, a arranjar a masseira.

\section{SAFO}

E tu estiveste a dar-lhe uma mão, claro está.

\section{FILÉNIS}

Não, senhora, eu não.

\section{SAFO}

Gosto pouco de mentiras, Filénis. E já sabes, tu e as outras também, que não quero familiaridades com o pessoal. Não foi para isso que vos mandaram para minha casa as vossas famílias.

\section{FILÉNIS}

Sim, senhora. (acaba de distribuir os copos pelas companheiras e senta-se)

MÉGARA (a Gôngila, com evidente sarcasmo)

E como vais representar essa tua Afrodite, toda nua, ou com um véu que lhe cubra as partes divinas?

GÔNGILA

Pois olha, esse é um pormenor em que ainda não pensei. Vejo-a a surgir de um mar azul que se torna branco com o bater das ondas nas rochas e se transforma em espuma. Mas a deusa ... Ainda não sei o que fazer com ela. Suponho que à medida que a vá pintando vai-me ocorrer como representá-la ...

MÉGARA (que prossegue com sarcasmo)

Ah, claro! Não me passou pela cabeça que te vai chegar uma inspiração repentina. O êxtase artístico, como se costuma dizer. Meninas, a partir de amanhã teremos uma nova musa, a décima, Gôngila, padroeira da pintura.

TELESIPA (que se levanta enfurecida e se confronta com Mégara, agarrando-a pelo queixo com uma mão, em tom ameaçador) 
Sim, a partir de amanhã ... como de amanhã? A partir deste momento, teremos uma nova musa, a décima, Mégara, padroeira das filhas da puta.

SAFO

Chega! A que vem esse comportamento? Telesipa, para a cadeira. Mégara, nem uma piada mais contra a tua companheira. Gôngila há-de fazer uma bela pintura sobre o nascimento de Afrodite, tenho a certeza. O tema é bonito, e o que menos importa é se a deusa, a beleza suprema, aparece nua ou vestida.

\section{GÔNGILA}

Obrigada, mestra. Foi por eu ter dito antes que a vou pintar em tua honra que Mégara ficou furiosa. Ciúmes, nada mais do que ciúmes. Queria-te toda para ela, só para ela. Pois eu vou-me pôr diante da tela, com as tintas, e começo a trabalhar recitando aqueles teus versos

De polícromo trono, imortal Afrodite

filha de Zeus que tramas intrigas, te suplico:

Nem a tormentos, nem a angústias submetas,

Senhora, este meu coração ...

Esta será a minha inspiração. Logo lhe acrescentarei o mar, as ondas, a costa ... E a pintura há-de sair-me formosa por si mesma.

\section{SAFO}

Já a espero com impaciência. Mas para já são as vossas disputas que me preocupam, essa agitação que se apoderou hoje de vós... Talvez a culpa seja deste calor insuportável. Também eu peço ajuda à Cipriota divina, para que instale a paz entre vocês, e entre vocês e eu, recordando-lhe a última estrofe daquele poema que agora mesmo tu começaste:

Vem até mim também agora, e livra-me

de penosos desvelos; quantos desejos

o meu coração anseia, cumpre-os; tu mesma

combate ao meu lado.

MÉGARA (que se aproxima, conciliadora, de Safo e a beija na face; enquanto assim procede, a poeta olha para Irana)

Safo, perdoa-me. Também eu dirijo as minhas súplicas a Afrodite, que de mim faz pouco caso. De toda a maneira, oxalá te conceda o que lhe pedes. Ver-te feliz, alegre, sorridente, é o maior desejo das tuas discípulas. De modo que haja paz, 
meninas: a nossa divina mestra não está muito bem; não lhe causemos mais aflições com tantas disputas.

(Faz-se um longo silêncio e uma imobilidade total: uma cena congelada, mas não excessivamente longa)

GIRINA (está a bordar alguma coisa como um paninho, sem dúvida para o enxoval. Solta um suspiro)

Vejam lá vocês, amigas. Dentro de quinze dias estarei em Mileto, nos braços da minha mãe, e dentro de dois meses em Sardes, enfim dona e senhora da minha casa ...

\section{FILÉNIS (interrompendo-a)}

Porque não dizes tu nos braços do teu homem?

\section{SAFO}

Deixa-te de impertinências, Filénis. De toda a forma, Girina, não creio que tenhas razões de queixa. Tudo se cumpre segundo os teus desejos. Quando te trouxe cá o teu pai, o que ele me confiou, e o que então era também o teu desejo, era isto: fazer de ti uma mulher como se diz que deve ser, culta, elegante, e sobretudo uma dona de casa exemplar. E ainda, se possível, amante ideal e fiel do seu marido. Pelo menos por uns anos, antes que o passar do tempo te derrame nos cabelos uma neve permanente. Não foi isso?

GIRINA (com dúvidas)

Foi, Safo.

\section{SAFO}

Na minha opinião, tudo isso já tu tens. O que possa ainda faltar à tua formação, compete à tua mãe ensinar-to agora em vossa casa, nos dias que faltam para o casamento.

\section{GIRINA}

Não é assim tão simples, mestra. Tu sabe-lo melhor do que ninguém. Tu mesma recitavas ainda há poucos dias não sei o que faça, pois dois projetos tenho. Pois a mim acontece-me justamente o contrário, projetos agora não tenho 
nenhum. Quando cá cheguei, a Mitilene, tinha tudo claro, porque na verdade nada tinha claro. Foi cá que descobri o que se esconde no teu coração, Safo, e no de todas vós; e aprendi os teus versos, e os de Irana, e as suas formosas canções ao som da lira. Escutei os vossos relatos de amor, os de todas, os verdadeiros e os inventados. Cada noite que passava, cada história nova, cada poema nunca antes escutado, iam-me apoucando o que no meu coração, antes, em Mileto, tinha sido a imagem adorável do meu Eucarião, alto e formoso como um Ares guerreiro. Esse tinha sido antes o meu projeto, mergulhar-lhe nos braços. Agora converteu-se numa dúvida, num temor: vou vê-lo tal qual na realidade é, baixo, um tanto gordote, com essa boa posição de que me falava o meu pai, mas que não creio que me faça vibrar de prazer quando me abraçar no leito.

\section{SAFO}

Ninguém nesta casa alterou essa imagem que tinhas do teu Eucarião, Girina: nenhuma de nós o fez encolher, engordar, ou o tornou vulgar, que adivinho que é o que realmente temes neste momento. Um homem é um homem, e ou gostas dele como ele é, ou não gostas. Ou o idealizas para o amares, porque gostas dele. Esse é o teu problema com Eucarião: antes de vires para cá podias compará-lo com um rebento novo ... e agora temes encontrá-lo semelhante ao tronco grosso e retorcido de uma velha oliveira. Um tronco enrugado e morto, num campo deserto. A explicação está no teu coração, não a busques noutro lado.

\section{GIRINA}

Mas então, Safo, quer dizer que o não amo?

\section{SAFO}

Eu sei lá! Pronuncia-lhe o nome na tua mente, reproduz-lhe a imagem no teu coração, ouve-lhe os latidos. Aí vais ter a resposta às tuas dúvidas.

GIRINA (depois de um breve silêncio, como se seguisse o conselho de Safo; todas as outras estão fixas nela)

Creio que o meu coração não tem resposta. O que vos diz o vosso coração, quando pensam num homem?

TELESIPA (rápida e contundente)

A mim não me diz absolutamente nada. 


\section{GÔNGILA}

Nem a mim.

MÉGARA

Eu sinto asco só de pensar num homem a apalpar-me e a penetrar-me.

\section{FILÉNIS}

Não sabes o que dizes, Mégara. É nessa hora que te sentes realmente mulher, quando um homem te acaricia até derramar dentro de ti o seu suco, enquanto te toca o corpo com as mãos, mergulha o olhar nos teus olhos e te mordisca com paixão a nuca, as orelhas, os lábios.

SAFO (a escutá-la, surpreendida)

Para ti está tudo claro, Filénis. Não há dúvida de que vais ser feliz. Só te falta um homem. Que seja forte, imagino eu, formoso, bem armado, não é? Está claro. É bom saber pelo que se anseia. Foi por um homem assim que Helena deixou a pátria, os pais, o marido, e tramou a que tramou em Tróia. Tu davas, não há dúvida, uma boa Helena. FILÉNIS

Já me satisfazia com menos, podes crer.

SAFO (em tom claramente depreciativo)

Eu sei, eu sei. Mas não podes ter a certeza de que esse seja o amor que Afrodite patrocina. E tu, Irana, não dizes nada?

\section{IRANA}

Não tenho nada para dizer, Safo. Sei muito bem o que é o amor, porque tu nos deste as chaves precisas para o reconhecer. Conheço-as todas, e quando as sentir na cabeça, no coração, nos sentidos, saberei que me encontro enfim perante o ser que amo.

\section{MÉGARA}

Referes-te àquele poema divino em que Safo crê que morre ao descobrir a sua amada conversando com um homem, e ela escondida, sem que a vejam, cheia de ciúmes, sente todos os sintomas de uma paixão sem limites, não é?

\section{IRANA}

Refiro-me a mil e uma coisas que aprendi com Safo, e naturalmente também ao tal poema. Nele está dito tudo. Quando sentires essas sensações ao observar uma pessoa, fica segura de que a amas. 
MÉGARA (com voz melosa, um pouco enjoativa)

Safo, peço-te, recita-nos esses versos.

$\mathrm{SAFO}$

Outra vez? Não e não. Estou farta. Que a Irana os recite, que os sabe bem, e os compreende melhor que ninguém.

\section{IRANA}

Mas são teus, mestra. Oxalá que eu, ao recitá-los, os não estrague:

Igual aos deuses me parece

o homem que, diante de ti, se senta

e se acerca, quando docemente falas

te escuta,

e quando ris, sedutora. É

o que me faz saltar o coração no peito.

Olho-te por um instante e a voz

escapa-se-me,

a língua prende-se e um subtil

fogo sob a pele corre ligeiro,

com os olhos nada posso ver,

os ouvidos zumbem,

cobre-me o suor, toda me invade

um tremor, fico mais verde

do que a erva. Parece que pouco me falta

para morrer.

FILÉNIS (depois de um curto silêncio geral)

Isso é o amor! Perder a palavra, ter ardor na pele, tremer, sentir que se nos rasgam as carnes, que se morre ... Isso é o amor! Comigo acontece quando tenho um homem em cima que me sabe manejar, e me domina, e me faz sentir dor e prazer, e me faz soltar gritos, e me conduz por fim ao cúmulo do gozo.

\section{SAFO}

Que bruta és, Filénis! Creio que vou ter de avisar a tua família de que aqui já não estás a fazer nada, que não tens grande coisa para aprender em minha casa. 


\section{FILÉNIS}

Estás a ser injusta comigo, Safo. O meu pai e a minha mãe mandaram-me para a tua companhia para eu me fazer uma mulher elegante, distinta, como compete a gente da sua classe. Mas tu és incapaz de me perdoar que me não interessem os teus versos, nem sequer os do Poeta, nem os de Alceu, nem as canções de Irana, nem as pinturas de Gôngila ... Mas não me interessam, que hei-de fazer?

\section{SAFO}

Cala-te, cala-te! Não vás por aí ...

\section{FILÉNIS}

Mas é a verdade. E digo-te mais, mestra. A Ilíada põe-me doente, com tantos heróis formosos, fortes e valentes, que não param de matar-se uns aos outros, numa carnificina interminável. E não achas bem que te diga que gosto de um homem, que sinto prazer quando me comprime com o seu corpo, e entra em mim como herói vitorioso. Se quiseres, digo-te o nome.

\section{SAFO}

Não te passe tal coisa pela cabeça, por Afrodite!

\section{FILÉNIS}

Mas vamos a ver uma coisa, mestra. Será que é proibido amar um homem? É o que sente a maioria das mulheres que por aí andam. Em contrapartida tu, julgo que pensas que o mundo do amor se encerra dentro desta tua residência das musas, que se reduz às tuas moças bem educadas, bem penteadas, bem vestidas, bem falantes, de andar discreto, que bordam, pintam, recitam, cantam ... mas há outro mundo fora destas paredes, Safo, onde existem esses seres apetecíveis que são os homens.

\section{SAFO}

Vejo que não tiras grande proveito das minhas lições.

\section{FILÉNIS}

Ora diz-me lá, anda, tu nunca tiveste prazer com um homem? Quando tinhas marido, e ias para a cama com ele, e quando geraste a tua filha, a linda Cleis, não te dava prazer? Ele não te saciava na cama? 
Cala-te de uma vez por todas! Não te permito que te metas na minha intimidade, que não te interessa para nada. Nem uma palavra mais. Não estou disposta a consentir tal insolência.

MÉGARA (a Filénis, enfadada)

Se prestasses atenção às poesias da mestra, não dizias tantas insolências. Onde se viu homens mais atrativos do que nos epitalâmios de Safo? Que homem pode ser mais sedutor do que Fáon, o barqueiro de Afrodite, que punha loucas todas as mulheres que o viam?

\section{FILÉNIS (que a confronta)}

Acabaste comigo, Mégara! O formoso Fáon dos poemas de Safo, belo como um deus, é o sujeito mais tonto que se pode encontrar em toda a poesia. Isto é que tu és entendida nos versos da mestra! Cega-te o amor que lhe tens. Mas haverá um indivíduo mais amaneirado, mais pegajoso, mais convencido, mais fátuo que o bom do Fáon? Pode haver maior ironia do que quando Safo diz que se vai lançar ao mar de uma rocha escarpada, porque Fáon a desdenha? Pois como vês, aqui a temos, sã e inteira, sentada ao nosso lado, e tão feliz. Afinal não se lançou dos penhascos, e menos ainda se viu desdenhada por esse estúpido. Não é assim, senhora?

\section{SAFO}

Pode ser.

\section{FILÉNIS}

Com os poemas de Fáon, com a sua beleza repelente, com a sua imbecilidade, os seus desdéns, o que pretendeste foi dar um conselho a rapariguinhas ingénuas. Um conselho que significa 'olho nos homens'!

\section{SAFO}

Não deixam de me surpreender as tuas interpretações.

\section{FILÉNIS}

Para depois dizeres, como há pouco, que não aprendo nada contigo.

GIRINA (cortando a conversa)

E tudo isto veio a propósito de eu regressar a casa, para me casar com o meu Eucarião, para me fechar noutra casa, que se dirá que é realmente minha, e cuidá-la, ra- 
lhar o dia inteiro com escravas preguiçosas, e criar um, dois, ou três filhos, até que se me deforme a tripa e as tetas me caiam até aos joelhos. Que dizes tu disto, Safo? $\mathrm{SAFO}$

Não sei o que te diga. Vejo esse teu desencanto, mas surpreende-me que tenha nascido tão depressa. Pergunto-me se alguma vez sonhaste realmente com esse Eucarião que nunca vi, se alguma vez pensaste que o amavas, se acreditaste de facto que podias vir a amá-lo.

\section{GIRINA}

E tu, senhora? Tu amaste alguma vez o teu marido?

\section{SAFO}

Não tenho a certeza. Não, não, creio que não o amei de verdade, nunca.

\section{GIRINA}

Nunca tiveste prazer com ele?

\section{SAFO}

Logo para começar, não. Sobre isso não tenho a menor dúvida.

\section{GIRINA}

Nunca amaste um homem, Safo?

SAFO (pensativa, com dúvidas)

Creio que sim. Sim, sim, uma vez sim. Mas o caso não foi por diante. Embora possivelmente ele também me amasse.

\section{IRANA}

Que pena! É triste o que estás a dizer.

\section{GIRINA}

É uma coisa difícil, o amor. Mas também não vale a pena passar a vida às voltas com ele. Eu, pela minha parte, deixo as coisas como estão. Quem sabe se, com o tempo, tudo se resolve! Quem nos pode dizer que não acabo por me acostumar a Eucarião? Decerto, Safo, não me vais deixar partir sem um epitalâmio para a minha boda, pois não?

\section{SAFO}

Claro que não. Já o tenho alinhavado. Só me falta poli-lo um pouco mais; e talvez alterar alguma coisa. 


\section{MÉGARA}

Senhora, por favor, recita-o para nós, alguns versos pelo menos.

\section{GIRINA}

Sim, Safo. Dá-me essa prenda.

\section{SAFO}

O problema é que ainda não lhe sei bem os versos de cor. Enfim, vamos lá a ver, só um bocadinho. Recordo-me de que, quando aparece o noivo, os rapazes da comitiva nupcial dizem assim:

Acima a trave mestra,

Hurra!

Ergam-na, carpinteiros,

\section{Hurra!}

O noivo entra, igual a Ares,

\section{Hurra!}

Muito mais alto do que um homem alto,

\section{Hurra!}

Pois bem, vou mudar pelo menos a do noivo alto, já que me dizes que o teu Eucarião atira mais para o baixito. As pessoas são muito maliciosas, tiram partido de tudo. E não te preocupes, Girina, vou tê-lo acabado para o dia da tua partida.

\section{GIRINA}

Obrigada, mestra. Ao menos vou pertencer ao número das mulheres do Egeu que se casam com um poema da maior das poetas.

\section{SAFO}

E mais alguma coisa, também. (Sorri, maliciosa) Há quatro ou cinco dias ouvi uns ensaios entrecortados de uma canção em que se falava de uma boda ... Suspeito de que ...

GIRINA (alvoroçada, pondo-se de cócoras diante de Irana)

É verdade que me fizeste uma canção, Irana? As Musas te cubram de bénçãos e te convertam na mais egrégia das poetas discípulas de Safo. Canta-me essa canção, por favor. 


\section{IRANA}

Ainda não está acabada.

\section{TODAS AS MOÇAS}

Canta, canta! Queremos ouvi-la. Anda lá.

\section{IRANA}

Está bem. Vamos a ver como sai. Mas insisto: ainda lhe falta uma fervura. Uma polidela, como manda Safo. Há coisas que me não satisfazem ainda (canta 'à capela' com música de Aurora López):

Cinge a terna noiva

os loiros cabelos

com rosas, margaridas

e violetas.

Cuidai ventos marinhos

da moça bela.

Cobre a terna noiva

o peito macio

com sedas orientais

e adereços.

Leva-a com cuidado,

feliz barqueiro.

Mostra a terna noiva

seu seio formoso

perfumado de jasmins

e de aneto.

Toca-lhe com ternura,

noivo trigueiro.

SAFO (comovida)

É uma canção linda. Muito linda, na verdade. Delicada. Deliciosa.

\section{IRANA}

Favor teu, mestra. Se algo de bom tem, às tuas lições se deve, com certeza. 


\section{GIRINA}

Vou recordar-me de todas vós quando ma cantarem no dia da boda. E depois vou aprendê-la eu mesma, e cantá-la, pensando em ti, Irana, quando estiver na minha casa, nas tardes infindáveis de primavera. Hei-de suplicar aos deuses que te premeiem por um presente tão belo. Que encontres um noivo que te trate, a ti também, com doçura. Ou que descubras uma mulher que te faça feliz, que te mime, que te adore. Estou certa de que já existe.

\section{IRANA}

É Afrodite quem manda nas coisas do coração, não os humanos. É da sua vontade que tudo depende.

\section{FILÉNIS}

E o que é um noivo trigueiro, Irana?

\section{IRANA}

É como o trigo, que não tem nada de loiro, e muito menos de moreno, vamos lá. A verdade é que me ocorreu porque me rimava bem no verso. Mas afinal, Girina, como é o teu Eucarião, refiro-me à cor? Nunca nos falaste dele. Assenta-lhe o trigueiro?

\section{FIRINA}

É moreno, moreníssimo; negro como pez! Mas não mudes o trigueiro, que é muito bonito. E tu, Safo, deixa aquela do mais alto do que um homem alto. Assim, na obscuridade da alcova, posso imaginá-lo distinto, tal como vocês duas o conceberam.

\section{FILÉNIS}

Ser baixo não é nenhum problema, desde que não seja anão. E ser morenaço, menos ainda. Sonhei mais de uma vez que me agarrava um negrote, e não me tocava com doçura, não, qual o quê! Que me fornicava a sério ... mas que me deixava tão repleta, tão saciada, tão satisfeita!

\section{SAFO}

Outra vez, Filénis! Que hei-de fazer contigo?

GÔNGILA

Deixa-a, mestra. Provavelmente há-de ser feliz com um homem que a agarre bem, como ela diz. É a Afrodite dela que a leva por esse caminho. Pois que se lhe faça 
a vontade. O importante é que a Cipriota te ponha diante dos olhos o objeto dos teus desejos, seja ele homem ou mulher.

\section{FILÉNIS}

Como aconteceu contigo e Telesipa, não é isso?

\section{GÔNGILA}

É isso sim, como aconteceu comigo e com Telesipa. Porque não reconhecê-lo? Onde está escrito que não possa querer, amar, gozar, uma mulher com uma mulher, ou um homem com um homem? A nossa mestra sabe-o bem.

\section{TELESIPA}

Não the vão recordar coisas que ela procura esquecer.

\section{SAFO}

Referes-te ao caso de Átis, Telesipa? Não estou a procurar esquecê-lo, porque foi um amor muito bonito, não o posso negar, e nada houve nele cuja recordação me envergonhe, ou de que tenha de arrepender-me. Se eu quisesse que se perdesse para sempre nas sombras do passado, não teria escrito e dado à luz pública tantos poemas sobre o meu amor por ela.

\section{MÉGARA}

Era uma imbecil! Uma imbecil rematada! Só assim se pode explicar que desandasse da tua casa para ir com a bruxa da Andrómeda.

\section{SAFO}

Não estou de acordo com isso que dizes, Mégara. Átis não era nenhuma imbecil. Era agora! De imbecil não tinha nada! Tinha um encanto divino, e eu amei-a de verdade. Disse-o mais de uma vez nos meus versos, com sinceridade. Foi uma história triste, a nossa.

\section{GÔNGILA}

Que pena! Uma catástrofe!

\section{SAFO}

Não, não. Uma catástrofe é outra coisa. Uma catástrofe pode ser uma guerra, ou a morte de uma criança que caia dentro de um poço traiçoeiro, ou a violação de uma menina por um soldado bestial, ou a morte de uma mulher ao dar à luz ... O que se passou com Átis foi uma história triste; uma história que começou por ser muito bela, e acabou asquerosa. Sim, penso que foi isso. 


\section{IRANA}

Muitas vezes falamos sobre isso entre nós, quando tu não estás presente. E parece-me que nos fartamos de fantasiar. Porque nos não contas tu como ela foi de verdade?

SAFO

É algo muito meu. Não creio que vos interesse.

\section{IRANA}

Mestra, se é algo muito teu, sem dúvida que nos interessa. E muito, aliás. SAFO

Então está bem. Vou dar-vos a versão autêntica dos factos. Não sei por que razão, Irana, sou incapaz de recusar qualquer pedido teu.

Um breve silêncio. Todas as moças se levantam e empurram as cadeiras para se acercarem mais de Safo. Fecham um círculo estreito à volta dela, como se a aconchegassem. Se é possível, enquanto dura o monólogo, deveria cair uma luz direta sobre o rosto da poeta, deixando na penumbra todas as outras raparigas.

\section{SAFO}

Átis chegou a minha casa por verdadeira casualidade. Era filha de uma mulher muito pobre, viúva, que às vezes vinha vender-nos uns limões, umas maçãs, uns punhados de azeitonas. Estão a ver, coisas que temos na horta que chegue e sobre. Mas eu sempre lhas comprava, porque me dava pena, uma mulher sozinha, com uma filha pequena ... ou se ajudava, ou acabava na prostituição. Um dia veio com a filha, e assim, sem mais, mal nos conhecíamos, pediu-me se podia deixá-la aqui uma temporada, só um mês ou dois, porque ia fazer uma viagem curta de barco, não me lembro para onde, e tinha medo de a levar com ela, pelo perigo dos piratas. Eu disse que sim, sem pensar duas vezes. Nunca mais voltou a buscar a filha. Átis já era então uma mulher, tinha quinze ou dezasseis anos, não sei bem, mas era tão miudinha, tão pouca coisa, que parecia ainda uma menina. (Mégara pronuncia, com voz muito baixa, of fragmento 'pequena me parecias e desengraça$\left.d a^{\prime}\right)$. Sim, nesse verso escrevi a primeira impressão que me produziu, pequena me parecias e desengraçada. Mas não passou disso, de uma primeira impressão. Era muito estranha. Se lhe fixavas a cara, não era nenhuma beleza, nem nada que se 
pareça. Na verdade tinha aquele nariz, tão grande e torto que estragava o conjunto. Mas em contrapartida, tinha aqueles olhos imensos, negros como o azeviche, com um branco tão límpido, que brilhavam de uma maneira ... Nunca voltei a ver olhos assim. E aqueles lábios tão finos, tão bem desenhados, de contorno tão formoso. E os dentes tão brancos, tão certos e bem nivelados: os dentes de uma deusa. Cada dia que passava ia descobrindo nela algo de admirável. Por exemplo, as mãos finas que ela tinha, tão suaves, com uns dedos afilados, e com umas unhas tão rosadas, com umas meias luas perfeitas. Quanto prazer me deram aquelas mãos! Depois descobri-lhe os seios, pequenos e redonditos; não tinham nada que ver com as tetas gordas que os homens, brutos, desejam. Um dia, não vai há muito tempo, vi-a na rua, com Andrómeda, com outra moça e uma velha. Passou muito perto de mim, cravando um olhar fugidio na calçada, como se me não tivesse visto, mas pude observar que levava os lábios tisnados de pomada vermelha, os olhos encarvoados, e, não sei como, os peitos inchados como as antigas mulheres minóicas. Como pôde estragá-la assim, essa grande filha da puta? Quando cheguei a casa, toda sufocada, escrevi aqueles versos contra Átis, pensando em Andrómeda:

Quem é essa tosca que te embruxa os sentimentos, Átis, que de tosca leva o vestido e os colares, e não sabe arrastar uns farrapos sobre os tornozelos?

Estou certa de que me enfureci bastante, mas não me arrependo nada. Aliás, como bem sabem, tratei de arranjar maneira de que lhe chegasse rapidamente o meu insulto poético, à casa de Andrómeda, essa infame.

O certo é que me enamorei dela. Deixou depressa de ser a menina pequena e desengraçada do primeiro dia. Enamorei-me de Átis com loucura; não deixava de pensar nela, de manhã, à tarde e à noite. De pensar somente nela, descuidando as minhas outras discípulas, as minhas amigas, esquecendo as minhas obrigações. Sonhava só com ir, ao entardecer, estender-me com ela na areia macia da beira-mar, longe de todas vocês, e respirar perto dela aquele perfume que tinha, de azeite de nardo, acercando cada vez mais o meu corpo do dela, e acariciar-lhe com um lírio do mar as faces, o colo, os peitos, o ventre, as nádegas. Podem crer, não foi uma ilusão poética que eu tenha inventado. Muitas vezes o sono nos surpreendeu na praia, depois de nos beijarmos, de nos abraçarmos, de nos acariciarmos, de ararmos mutuamente os nossos corpos até ao orgasmo; muitas vezes nos despertou a chegada da Aurora de sandálias douradas ao levantar-se sobre o mar.

Mas Afrodite deixou de escutar as minhas preces e de ser-me propícia demasiado depressa. Andrómeda, essa asquerosa, que tem a capacidade de converter em 
esterco tudo o que ouve, vê ou toca, teve por Átis um capricho, sem dúvida por ter sabido que eu a amava com paixão. Começou a espiar-lhe as saídas, embora eu não permitisse a Átis que cruzasse o umbral da porta sozinha, e a mandar-lhe mensagens, e a prometer-lhe mundos e fundos, a cobri-la de presentes, a convertê-la na primeira das suas discípulas, ou até na chefe de todas. Por fim acabou por oferecer-lhe quantidades de dinheiro, que não sei se lhe chegou a dar alguma vez. E Átis foi-se com Andrómeda. De nada valeram os meus protestos de amor, nem que lhe recordasse os belíssimos momentos que tínhamos passado juntas, nem que a advertisse de que a intenção da porca da Andrómeda não era mais do que um capricho passageiro, sobretudo para me humilhar a mim. Tempo perdido! Uma vez, já no final, disse-lhe que se tinha esquecido dos versos e das canções, que no círculo de Andrómeda se não cultivam, porque a pobre é pouco dotada para a poesia e para a música. Compreendi que a tinha perdido definitivamente, porque, pela primeira vez, respondeu-me de forma muito desabrida, que dos meus versos estava farta até à ponta dos cornos. Perdoem-me, mas foram essas as palavras que ela usou. Foi recordando esse momento tão triste, tão vergonhoso, que escrevi aqueles versos, que the fiz chegar quando nos abandonou. Ao afastar-se para sempre da poesia, eu augurava-lhe

\section{E morta hás-de jazer, e não haverá de ti memória um dia, nunca, no tempo que há-de vir; porque não participas das rosas da Piéria; mas, invisível até na mansão de Hades, irás errante entre apagados mortos, caída do teu voo.}

Arrependi-me de ter-lhe escrito palavras tão cruéis, mas custou-me muito a recuperar-me, muito a começar a esquecê-la. Sei muito bem que sempre, antes ou depois, vocês hão-de partir. Sei-o muito bem. É a lei da vida. Houve despedidas que me custaram noites inteiras de dor e lágrimas. Recordo que alguma coisa se me quebrou dentro do peito quando partiu Anactória, porque nem ela queria ir-se, nem eu que ela fosse. Mas esperavam-na o pai, um ancião, a mãe, doente, e o seu prometido Eumelo, um loiro formoso de olhos verde azeitona, que fez dela a mais feliz das esposas, e feliz continua a fazê-la ainda. Foi penosa, a partida de Anactória. E vai ser penosa a partida da nossa Girina. Mas é por uma boa causa. A partida de Átis, pelo contrário, é talvez a história mais triste de toda a minha vida.

Faz-se um silêncio comedido, total, de que não sabem como sair, nem o que dizer. Por fim é a própria Safo que o rompe, superando a tristeza. 
Ala, ala! Afastem um pouco as cadeiras, que me sinto abafar. Alegrem-me essas caras. Mais vale não nos prendermos ao passado, nem nos envolvermos em recordações de bons momentos que já passaram. Aliás, julgo que no meu coração se acende uma nova luz. E se não fosse bastante, tenho-vos a vocês, que é o melhor que me pode acontecer.

\section{MÉGARA}

O que eu não daria para ser esse novo resplendor da tua existência!

\section{GÔNGILA}

Vamos lá, Mégara. Não atires tão alto. Olha para Safo como para uma deusa, ama-a, respeita-a, mas pensa que nos pertence a todas.

\section{MÉGARA}

O amor é egoísta, exclusivista. Não admite partilhas.

\section{IRANA}

O amor é cego, irrefletido, indomável. Não se deixa conduzir.

\section{FILÉNIS}

Sendo assim, Irana, havia que desculpar o abandono de Átis.

\section{IRANA}

Não creio, porque, na minha opinião, o que se passou com Átis foi uma perversidade, e o amor não deve ser perverso. Não sei se Safo pensa de outra maneira, mas Átis era ainda uma cria, muito irrefletida, atrevo-me até a dizer que com pouca visão. Deixou-se arrastar por Andrómeda, para que nos havemos de iludir, sabemos de sobra que uso lhes dá essa má mulher, essa górgona. A nós as nossas famílias enviam-nos para sermos educadas em casa de Safo, mas a ninguém passaria pela cabeça levar as filhas à de Andrómeda. Seria como deixá-las num prostíbulo, com o pretexto de as preparar para o casamento.

\section{SAFO (dissimulando, porque no fundo lhe agrada a crítica a Andrómeda)}

Meninas, chega de má língua. Andrómeda é má pessoa, não tenho a menor dúvida, mas na realidade o seu maior defeito reside numa terrível ignorância, numa carência absoluta de qualquer tipo de educação. 


\section{TELESIPA}

E na cepa que a pariu.

\section{GÔNGILA}

E na inveja que a corrói.

\section{IRANA}

E no mau gosto que a domina.

\section{GIRINA}

Para mim, é asquerosa.

\section{FILÉNIS}

Eu acho que está a precisar é de um homem que a meta nos eixos e lhe chupe o suco.

\section{SAFO}

Há um pouco de tudo isso que vocês dizem, estou de acordo. Menos com a solução que tu propões, Filénis.

\section{FILÉNIS}

Estranho seria que te agradasse uma sugestão minha, Safo. Mas tenho outras: por exemplo, podia Andrómeda transferir a sua casa para o bairro do porto, e montar lá uma casa de mulheres para serviços noturnos. Uma casa de putas, melhor dizendo.

SAFO

Sempre tens de te sair com uma expressão vulgar, porque sabes que me desagrada.

\section{FILÉNIS}

Mas pelo menos hás-de reconhecer que Andrómeda e as suas moças formam um grupo esquisito, muito suspeito. Há quem diga que por vezes ronda por ali um homem, a altas horas da noite. A mim não me surpreendia que aquela desavergonhada estivesse a ganhar um bom dinheirinho à custa das discípulas.

\section{SAFO}

Por Zeus, como é possível tal coisa? 


\section{FILÉNIS}

Não foi a vender-se a ela, com certeza, que já lhe sobram as peles por todo o lado, com aquela cara, fronte, pescoço, cheios de sulcos que nem campo semeado. Não, ela, com os homens, já deu o que tinha a dar. Em contrapartida, as moças, já se vê, como Átis ...

SAFO

Não digas isso, por Afrodite!

\section{FILÉNIS}

Pois se tu mesma acabas de dizer que sai com ela a passear toda pintalgada, nem que fosse uma cachorra. Alguma coisa se tem de passar.

\section{SAFO}

Enfim, vamos é mudar de assunto. (Dá-se conta de que Gôngila tem os olhos molhados) Gôngila, minha menina, a que vêm essas lágrimas? Que se passa? GÔNGILA (a limpar as faces, e a assoar-se)

Nada, mestra. Não é nada. Tontarias que me passam pela cabeça.

SAFO (põe-se de cócoras diante da cadeira de Gôngila e acaricia-a)

Mesmo que sejam tontarias, tens de mas contar. Tu és, em minha casa, a menina mimada, e dói-me ver-te chorar. Que se passa?

\section{GÔNGILA}

Quando falavas do teu amor por Átis, eu estava a ver-me a mim mesma. Telesipa era como tu, eu como Átis. Tu sabes quanto nos queremos uma à outra, mestra. Bom, na verdade todas vocês o sabem.

\section{SAFO}

Claro. E é uma coisa bonita. Transparece nessa alegria de viver que te embarga. Quando te pões a cantarolar enquanto pintas, é como se uma andorinha pousasse numa latada para nos saudar. Porque te pões a chorar, então? Pensa antes que és uma protegida de Afrodite, a divina Ciprogénia de áurea coroa.

\section{GÔNGILA}

Mas pensa no fim de Átis ... 
Que tens tu a ver com isso? Que te importa a ti essa Andrómeda desprezível, os seus planos perversos, e todas as que a acompanham?

GÔNGILA

Nada, para falar verdade. Mas pensa na partida da Anactória ... SAFO

E o que tem a ver contigo? Anactória partiu a chorar, é certo, mas só porque tinha de se separar de nós, para ir em busca da felicidade por que tanto ansiava. Recorda aquela expressão que lhe vimos quando veio visitar-nos na semana passada, com a bebezinha tão bochechuda e tão rosada. Era a imagem da felicidade perfeita. (Safo volta para a cadeira)

\section{GÔNGILA}

Muito alegre fiquei de a ver tão contente, Safo. No entanto os meus desejos não vão por esse caminho. (Telesipa foi-se aproximando, beija-a na face e pega-Ihe na mão com carinho. Gôngila põe-se a chorar outra vez) Esta é a minha vida, mestra. Que será de mim quando me separarem de Telesipa? Como vou poder viver sem ela?

SAFO

Ninguém vos pode separar. Quando chegar esse momento, logo se verá o que se pode fazer.

GÔNGILA

Estou certa de que o meu pai não vai tardar a mandar alguém a Lesbos para vir buscar-me. Não há-de descansar enquanto me não vir casada com um amigo que ele tem, que ficou viúvo.

\section{SAFO}

E a tua mãe, o que acha? Porque ela conhece o vosso caso, não é verdade?

\section{GÔNGILA}

A minha mãe sabe de tudo, e fica contente por eu me sentir feliz com Telesipa. Além disso, não gosta nada do marido que o meu pai me tem previsto. Mas a minha mãe é uma mulher casada, Safo, e as mulheres casadas não têm opinião. E se alguma vez a têm, tanto pior para elas, porque a sua opinião vale menos do que a de um criado homem. 
Sim, desgraçadamente é a realidade. Mas há-de haver uma saída, uma solução se há-de arranjar. Havemos de procurá-la entre todas. Afrodite há-de inspirar-nos algum recurso, tenho a certeza. Sei com toda a segurança que nos não há-de abandonar em tal apuro.

FILÉNIS (de repente)

Eu tenho uma solução.

SAFO (apanhada de surpresa)

Sim? Que te passou pela cabeça, Filénis?

\section{FILÉNIS}

Tu adota-las.

SAFO

Que queres tu dizer?

\section{FILÉNIS}

Isso mesmo, que as adotes. Quando o pai da Gôngila prevenir de que alguém a vem buscar, tu respondes que a adotaste como filha. E outro tanto a Telesipa.

SAFO

Como é que isso pode ser?

\section{FILÉNIS}

Não tem qualquer problema. Tu não dependes de ninguém, tens a tua casa, dinheiro é o que te não falta, a tua filha Cleis está casada, já pertence a outra família, não risca nada na tua casa.

\section{SAFO}

Mas continua a ser minha filha.

\section{FILÉNIS}

Mais filhas tuas somos nós, que estamos contigo dia e noite, na tua casa, ao teu cuidado. Mais filhas tuas são Gôngila e Telesipa, que precisam de ti para continuarem juntas enquanto se amarem. Sim, sim, Safo, não tenhas dúvidas. Essa é a solução, adota-as. E para que a coisa tenha a força legal que é necessário, faz testamento e deixa às duas a tua casa por herança. 
SAFO

Talvez não seja um disparate o que tu estás a dizer.

\section{FILÉNIS}

Faz o que te digo, Safo. Adota-as sem hesitares um só minuto que seja. Verás que resulta perfeitamente.

SAFO (depois de um silêncio, com admiração)

Que coração imenso tu tens, Filénis! Essa bondade não fui eu que ta ensinei, nem a tua mãe, nem ninguém. Vem-te desse coração imenso que albergas no peito.

\section{IRANA}

Acaba com esses soluços, Gôngila. Vais ser a filha adotiva da poeta e irmã adotiva da tua Telesipa. Não podes pedir mais.

\section{GIRINA}

Tens razão. E para celebrar esta ideia fantástica de Filénis, podemos cantar a Gôngila aquela canção tão bonita que fizeste com o poema que te dedicou Safo no teu aniversário.

\section{IRANA}

De acordo. Eu canto a primeira estrofe, e vocês a segunda. Pode ser?

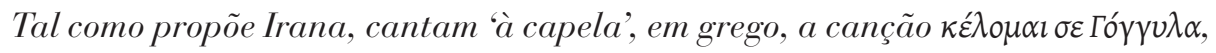
com música de Manos Jatsidakis. Os versos são de Safo, e devem interpretar-se com a pronúncia clássica, como faz Maria Faranduri.

\section{IRANA}

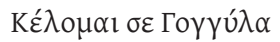

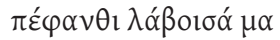

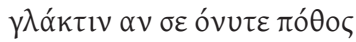

$\tau^{\prime} \alpha \mu \varphi \imath$ iлó $\alpha \tau \alpha$ l.

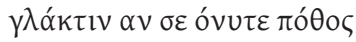

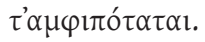


TODAS (também Safo)

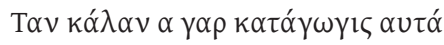

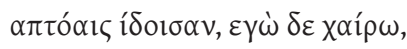

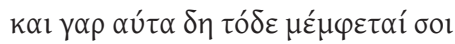

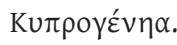

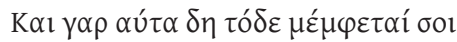

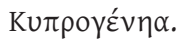

\section{IRANA}

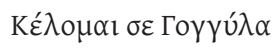

$\pi \varepsilon \dot{\varphi} \varphi \alpha v \theta \imath \lambda \alpha \beta_{\beta}$

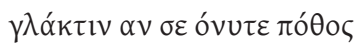

$\tau^{\prime} \alpha \mu \varphi$ iлót $\alpha \tau \alpha$ l.

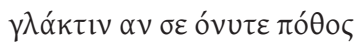

$\tau^{\prime} \alpha \mu \varphi \imath \imath \cot _{\alpha} \tau \alpha \mathrm{l}$.

Risos e bulício. Um silêncio curto. De repente, Safo desata em soluços. As moças rodeiam-na com preocupação.

\section{GIRINA}

Que tens, Safo?

MÉGARA

Dói-te assim tanto a cabeça?

SAFO (a chorar)

Não, não é a cabeça.

GÔNGILA (emocionada)

Diz-nos o que se passa. Diz lá!

SAFO (a limpar as lágrimas)

Esta manhã, muito cedo, desci ao porto com a Lídia, para a ajudar a escolher o peixe ...

\section{MÉGARA}

Porque não me chamaste? Sabes que adoro ir ao porto contigo. 
Vocês estavam ainda a dormir. Havia um barco de fora, não sei de onde, não muito grande ... (Rompe de novo em soluços) Apesar de estar algo distante, via-se perfeitamente que levava mulheres negras, raparigas negras, ou até mesmo meninas, todas com as mãos atadas, suponho que para impedir que se atirassem ao mar para fugir.

\section{TELESIPA}

Eu vi um assim uma vez. Vêm das costas africanas, onde roubam as mulheres, ou as compram. Atracam no nosso porto só para comprar água e provisões, e depois vão-se, para outros destinos.

IRANA (enérgica)

E ali vendem-nas como escravas.

\section{FILÉNIS}

E se têm menos sorte, como putas.

SAFO

Não! Isso não!

\section{FILÉNIS (abraçando Safo com carinho)}

Sim, Safo. É assim. É um negócio bastante corrente. O meu pai contou uma vez lá em casa, ao voltar de Pérgamo, que tinha visto um leilão de moças e de rapazes estrangeiros, e não só negros. Vendiam-nos para a prostituição.

\section{IRANA}

Deveriam ser impedidos pela lei.

SAFO

Não há lei com força suficiente quando se trata de comércio.

MÉGARA

E tu, não protestaste, Safo?

\section{SAFO}

Protestei, perante a guarda do porto. Responderam-me, com mais sorna do que respeito, que tudo o que podiam fazer era impedi-los de vir a terra, comprar 
provisões ... E então, disseram-me, seriam as escravas negras as primeiras a ficar sem comer nem beber.

\section{IRANA}

É sempre a mesma coisa. Aconteça o que acontecer, veja-se o que se veja, pense-se o que se pense, nós as mulheres nunca conseguimos fazer nada.

SAFO (triste, reflexiva)

Não muito, realmente. Mas alguma coisa, sim. Claro que sim! Por exemplo, podemos discordar. E podemos preparar-nos, cada vez mais, cada vez melhor, para o dia em que possamos fazer alguma coisa.

IRANA (incrédula)

E haverá esse dia?

\section{SAFO}

Tem de haver.

\section{IRANA}

E quando será esse dia?

\section{SAFO}

Alguma vez tem de chegar. (Reflete por um momento) Sim, terá de chegar alguma vez. (Outro instante de silêncio) Quero confiar que não tardará.

Safo passa de novo um lenço pelas faces, levanta-se e arranja as pregas do vestido. Dirige-se a todas.

\section{SAFO}

Meninas, chega por hoje. São horas de nos retirarmos. Passem pela sala de jantar e tomem alguma coisa antes de ir para a cama, uma fruta, uma fatia de queijo, umas azeitonas ... Mas não se deitem sem comer alguma coisa. E não façam muito barulho. Ainda me dói a cabeça.

GÔNGILA

E tu, não ceias nada, mestra?

SAFO

Não. Fico-me por um copo de água. 


\section{MÉGARA}

Queres que te leve uma infusão de cidreira e alfazema, com umas gotitas de mel? SAFO

Não, não. Agradeço-te. Deixa-me tranquila, estou muito cansada.

Vão saindo lentamente as moças, Telesipa e Gôngila de mão dada. A última é Filénis. Ao chegar à porta, aparece o porteiro, que lhe faz um sinal dissimulado, como para se verem depois. Safo espera um momento e dá ordens ao Porteiro. Ele gesticula, mas não pronuncia uma só palavra.

\section{SAFO}

Antes de saíres, arruma as cadeiras e rega um pouco os gerânios, que estão murchos do calor. Pouca água em cada floreira, para não transbordar.

PORTEIRO (diz que sim com a cabeça)

\section{SAFO}

Concordas sempre com tudo, mas sempre aparecem todas com regos de terra.

PORTEIRO (diz que sim com a cabeça)

SAFO

Apaga tudo, e não te esqueças de trancar a porta da rua.

PORTEIRO (com o mesmo gesto)

SAFO

Depois, vai dormir para o alpendre.

PORTEIRO (com um gesto de assentimento, não muito convincente) SAFO

Amanhã tenho de falar contigo. Há regras que não podem deixar de ser cumpridas em casa de Safo de Mitilene. (Sai devagar, majestosa, enquanto a luz do pátio se vai apagando; nele fica apenas o Porteiro, imóvel). 